\title{
Interleukin 1 Stimulates Platelet-activating Factor Production in Cultured Human Endothelial Cells
}

\author{
Federico Bussolino, * Ferruccio Breviario,‡ Ciro Tetta,\$ Massimo Aglietta," Alberto Mantovani,‡ and Elisabetta Dejana‡ \\ *Cattedra di Chimica e Propedeutica Biochimica; $¥$ Istituto di Ricerche Farmacologiche Mario Negri, 20157 Milan, Italy; §Laboratorio di \\ Immunopatologia, Cattedra di Nefrologia; "Clinica Medica A, Università di Torino, 10126 Torino
}

\begin{abstract}
Monocyte-derived interleukin 1 (IL-1) was found to be a potent inducer of platelet-activating factor (PAF) in cultured human vascular endothelial cells (HEC). The product was identified as PAF by its behavior in chromatographic systems, its recovery of biological activity, and its physico-chemical properties and susceptibility to lipases. The response of HEC to IL-1 was concentration-dependent, took more than $2 \mathrm{~h}$ to become apparent, and decreased after $18 \mathrm{~h}$ of incubation. Most of the PAF produced was cell-associated and only a small amount (about $25 \%$ of the total) was released in the culture medium. To study the mechanism of IL-1-induced HEC-PAF production we tested the activity of 1-O-alkyl-sn-glycero-3-phosphocholine:acetyl/coenzyme A acetyltransferase in HEC. Acetyltransferase activity measured in IL-1-stimulated HEC lysates showed a three to five times greater maximum velocity, but the same Michaelis constant, as untreated cells.

The regulation of PAF generation in HEC by IL-1 may be an important aspect of the two-way interaction between immunocompetent cells and vascular tissue.
\end{abstract}

\section{Introduction}

Recent observations suggest that there is a two-way interaction between the immune system and vascular tissue (1). Products synthesized by lymphomononuclear cells affect several vascular cell functions in vitro and in vivo (2-7). More recently, interleukin 1 (IL-1), ${ }^{1}$ a lymphokine produced by stimulated monocytes and macrophages and known to induce differentiation and proliferation of $\mathrm{T}$ lymphocytes (8), was found to interact with human endothelial cells (HEC) in culture, inducing synthesis of thromboplastin (9) and prostacyclin (10) and increasing adhesion of leukocytes on the cells (11).

Platelet-activating factor (PAF; 1-o-alkyl-2-acetyl-sn-glycero3-phosphocholine), a highly potent lipid mediator of inflammation and cell-cell interaction (12-14), belongs to a recently

\footnotetext{
Address correspondence to Dr. Dejana.

Received for publication 6 August 1985 and in revised form 7 February 1986.
}

1. Abbreviations used in this paper: acetyl-CoA, acetylcoenzyme A; HEC, human endothelial cells; HPLC, high pressure liquid chromatography; IL-1, interleukin 1; L-PC, lyso-phosphatidylcholine; LPS, lipopolysaccharide; PAF, platelet-activating factor; PC, phosphatidylcholine; PCA, tissue procoagulant activity; $\mathbf{P G l}_{2}$, prostacyclin; PMNS, polymorphonuclear leukocytes; $R_{f}$, retention front on TLC; TLC, thin-layer chromatography.

J. Clin. Invest.

(C) The American Society for Clinical Investigation, Inc.

0021-9738/86/06/2027/07 \$1.00

Volume 77, June 1986, 2027-2033 discovered class of autacoids. This compound has potent biological effects on both inflammatory and noninflammatory cells. It causes the activation of platelets, neutrophils, and monocytes (12-14) and increases $\mathrm{Ca}^{2+}$ membrane permeability of $\mathrm{HEC}(15)$. In vivo PAF induces bronchoconstriction and vasospasm, and increases vascular permeability and hepatic glycogenolysis (1214, 16). PAF, originally described as a product released from IgE-sensitized rabbit basophils (17), is also released from neutrophils, monocytes, and platelets (12-14). More recent experimental evidence indicates that rabbit endothelium and HEC can produce and release PAF during antibody-induced vascular damage or when stimulated with thrombin, angiotensin II, vasopressin, and ionophore A23187 (18-20). The ability of HEC to produce PAF seems relevant in pathophysiological conditions characterized by the interaction between circulating cells and the endothelium $(21,22)$. We report here that crude, purified, and recombinant IL-1 promotes PAF generation and release in HEC in culture.

This new activity of IL-1 may be an important aspect of the interaction between immunocompetent cells and vascular tissue.

\section{Methods}

Materials. The chemicals used and their sources were as follows. PAF (1-O-octadecyl-2-acetyl-sn-glycero-3-phosphocholine) and lyso-PAF (1O-octadecyl-sn-glycero-3-phosphocholine) were obtained from Bachem. Feinkemikalien AG, Bubendorf, Switzerland. $\left[{ }^{3} \mathrm{H}\right]$ acetylcoenzyme A (acetyl-CoA; $1 \mathrm{Ci} / \mathrm{mmol}$, specific activity adjusted by addition of unlabeled acetyl-CoA), L-3-phosphatidyl-[ $N$-methyl- $\left.{ }^{3} \mathrm{H}\right]$ choline-1,2 dipalmitoyl $(50 \mathrm{Ci} / \mathrm{mmol})$, and OCS scintillation liquid were purchased from Amerșham International, Amersham, Buckinghamshire, England. AcetylCoA, bovine serum albumin, hirudin, phospholipase $A_{2}$ from pig pancreas, phospholipase $C$ from Bacillus cereus (type III), lipase $A_{1}$, from Rizophus arrizus, dithiotreitol, phosphatidylcholine (PC), lyso-phosphatidylcholine (L-PC), cycloheximide, and polymixin B were obtained from Sigma Chemical Co., St. Louis, MO. Lipopolysaccharide (LPS) from Salmonella enteriditis was purchased from Difco Labs, Detroit, MI; thinlayer chromatography (TLC) plates (60F254) from Merck, Darmstadt, Federal Republic of Germany; silicic acid (Silic AR) from Mallinckrodt Inc., Science Products Div., St. Louis, MO; aspirin from Fluka AG, Buchs, Switzerland; CV-3988 from Takeda Chemical Industries, Osaka, Japan; and 1- $\left[{ }^{14} \mathrm{C}\right]$ palmitoyl-sn-glycero-phosphocholine $(95 \mathrm{mCi} / \mathrm{mmol})$ from Amersham International.

1-[14 C]palmitoyl-2-acetyl-sn-glycero-3-phosphocholine was prepared by incubating $200 \mu \mathrm{Ci}$ of dried $1-\left[{ }^{14} \mathrm{C}\right]$ palmitoyl-sn-glycero-3-phosphocholine overnight at room temperature with $2 \mathrm{ml}$ of acetic anhydride and $2 \mathrm{ml}$ of piridine (23)

High pressure liquid chromatography (HPLC) grade solvents (Merck) were filtered before use through Millex-SR filters $(0.5 \mu \mathrm{m}$ diameter; Millipore Co., Bedford, MA). All lipids, except L-3-phosphatidyl-[ $N$-methyl${ }^{3} \mathrm{H}$ ]choline-1,2 dipalmitoyl, were thin-layer chromatographed (chloroform/methanol/water; 65:35:6, vol/vol as solvent system).

$\mathrm{CV}-3988$ was diluted in $0.15 \mathrm{M} \mathrm{NaCl}$ heated to $60^{\circ} \mathrm{C}$ and then buffered to $\mathrm{pH} 7.4$ with $1 \mathrm{~N} \mathrm{NaOH}$.

Aspirin was diluted in $0.15 \mathrm{M} \mathrm{NaCl}$ and buffered to $\mathrm{pH} 7.4$ with 
$\mathrm{NaOH}$. Recombinant interleukin 2 was obtained from Biogen Research Corp., Cambridge, MA and interferon- $\alpha$ and $-\gamma$ from Hoffman-La Roche, Nutley, NJ. Natural interferon- $\beta$ was purchased from Serono, Rome, Italy.

Phytohemagglutinin (HA 17) was obtained from Wellcome Research Labs, Beckenham, England.

All culture reagents were purchased from GIBCO, Paisley, Scotland. The plastic flasks and petri dishes came from Falcon Labware, Div. of Becton, Dickinson \& Co., Oxnard, CA.

IL-1 preparations. Crude IL-1 was obtained from culture supernatants of Percoll-purified (24) monocytes $\left(2 \times 10^{6} / \mathrm{ml}\right.$ RPMI 1640 medium with $5 \%$ fetal bovine serum) stimulated with $25 \mu \mathrm{g} / \mathrm{ml} \mathrm{LPS}$ as described (25). The supernatants were precipitated with $75 \%$ ammonium sulfate and dialyzed against phosphate-buffered saline.

Highly purified IL-1 (Ultrapure IL-1; Genzyme Inc., Boston, MA) was obtained from supernatants of Staphylococcus albus-stimulated monocytes, by absorption on rabbit antibodies coupled to a Sepharose 4B column. After elution from the column, the material, further purified by chromatography on Sephadex G50, gave a homogenous band on sodium dodecyl sulfate-polyacrylamide gel electrophoresis as described (26).

Purified recombinant murine IL-1 (Lot 14430-21) was obtained from Dr. Peter Lomedico at Hoffman-La Roche (27). It was supplied in $5 \mathrm{M}$ guanidine- $\mathrm{HCl}$, and therefore, in some experiments, appropriate controls with guanidine were run with no induction of PAF.

In the crude, purified, and recombinant IL-1 preparations, thymocyte co-stimulatory activity was independently evaluated in a co-stimulator assay with $\mathrm{C} 3 \mathrm{H} / \mathrm{HeJ}$ thymocytes as responding cells and phytohemagglutinin $(0.5 \mu \mathrm{g} / \mathrm{ml})$ as stimulus (10). A partially purified IL-1 preparation (28) (kind gift from Dr. G. Scala, School of Medicine, University of Naples, Naples, Italy) was assigned a $1000-\mathrm{U} / \mathrm{ml}$ value and used as a standard in each assay. Results from triplicate cultures were plotted on a linear regression against the standard preparation and expressed in units per milliliters.

In purified and recombinant IL- 1 the absence of endotoxin $(<0.1$ $\mathrm{ng} / \mathrm{ml}$ of a solution containing $100 \mathrm{U} / \mathrm{ml} \mathrm{IL-1)}$ was documented by Limulus assay (Sigma Chemical Co.).

Endothelial cell culture. HEC were cultured, as previously described (29), in medium 199 supplemented with $20 \%$ newborn calf serum and used at the first passage at confluence.

HEC stimulation with IL-1. After removal of the growth medium, the monolayers of intact confluent HEC $\left(1.5-2 \times 10^{5}\right.$ cells in a 4-cm ${ }^{2}$ culture well) were washed once with $2 \mathrm{ml}$ phosphate buffered saline. Each well was then incubated with $1 \mathrm{ml}$ of serum-free culture medium containing $0.25 \%$ bovine serum albumin in the presence or absence of acetyl-CoA and IL-1 at the required concentration.

In some experiments aspirin, hirudin, cycloheximide, and polymixin $B$ were added to the cells for the duration of the experiment.

After selected incubation times at $37^{\circ} \mathrm{C}$, the supernatants were removed from the culture wells, centrifuged for $5 \mathrm{~min}$ at room temperature in a microfuge (Beckman Instruments, Inc., Fullerton, CA), and the cells detached with a rubber policeman. Lipids were extracted from the supernatants and the cells according to Bligh and Dyer (30).

$P A F$ purification. Lipid-containing, chloroform-rich phases were applied to a silicic acid chromatographic column and eluted with chloroform, acetone-methanol (1:1, vol/vol), and chloroform-methanol (1:4, vol/vol) (31). From the last fraction, PAF was isolated by TLC with chloroform/methanol/ $\mathrm{H}_{2} \mathrm{O}(65: 35: 6, \mathrm{vol} / \mathrm{vol})$ as solvent system (32). The lipid material, with a retention front $\left(R_{f}\right)$ from 0.15 to 0.22 , was extracted (32) and used for biological assay and characterization as described below.

$P A F$ assay. PAF was detected by aggregation of washed rabbit platelets (33). The amount of PAF was expressed in $\mathrm{ng} / 1.5 \times 10^{5}$ cells and calculated over a calibration curve of synthetic PAF constructed for each test (19).

$P A F$ characterization. TLC-purified PAF from each well was resuspended in $0.5 \mathrm{ml}$ isopropanol- $n$-hexane $(1: 1, \mathrm{vol} / \mathrm{vol})$. HPLC was performed (34) using a double-pump model 342 M system (Beckman Instruments, Inc., Geneva, Switzerland), equipped with an ultrasphere $\mathrm{Si}$
5 column (Altex Rainin, Berkeley, CA), and connected to a UV-visible detector (204 nm; LKB Produkter AB, Bromma, Sweden). From 2.5 to $10 \mu \mathrm{l}$ samples were injected in the column using a model 210 injector (Beckman Instruments, Inc.) with a 20- $\mu$ l sample loop. The column was eluted at a flow rate of $2 \mathrm{ml} / \mathrm{min}$ using a solvent system of $96 \%$ isopropanol- $n$-hexane $(1: 1, \mathrm{vol} / \mathrm{vol})$ (solvent $\mathrm{A})$ and $4 \% \mathrm{H}_{2} \mathrm{O}$ (solvent B) with a linear gradient to $8 \%$ solvent $\mathrm{B}$ over a 15 -min period after injection.

Synthetic PAF, PC, and L-PC were used as standard markers. PAF activity of IL-1-stimulated HEC resolved in a unique peak that coeluted with synthetic PAF and PAF derived from A23187-stimulated HEC (19) between PC and L-PC, showing a retention time of 13-16 min (Fig. 1). The peak resolved by HPLC containing the biologically active material was characterized as PAF by comparison with synthetic PAF and PAF derived from A23187-stimulated HEC according to the physicochemical (32) and lipase treatments (35).

PAF activity was destroyed after base-catalyzed methanolysis $(0.03$ $\mathrm{N} \mathrm{NaOH}$ in methanol for $3 \mathrm{~min}$ at $22^{\circ} ; 0-1 \%$ recovered activity) and treatment with phospholipase $\mathrm{A}_{2}(0.03 \mathrm{mg} / \mathrm{ml}$ Tris-buffered saline, $\mathrm{pH}$ 8 , containing $10 \mathrm{mM} \mathrm{CaCl}_{2}$ for $1 \mathrm{~h}$ at $37^{\circ} \mathrm{C} ; 0-3 \%$ recovered activity) indicating the presence of an ester linkage at sn-2.

Substitution via an alkyl ether linkage at sn-1 was assessed from the lack of effect of acidic treatment $\left(0.03 \mathrm{~N} \mathrm{HCl}\right.$ in water for $3 \mathrm{~h}$ at $22^{\circ}$; 96-100\% recovered activity) or lipase $A_{1}(0.1 \mathrm{mg} / \mathrm{ml}$ borate buffer 0.1 $\mathrm{M}, \mathrm{pH} 6.5$, containing $10 \mathrm{mM} \mathrm{CaCl}_{2}, 1 \mathrm{mM}$ deoxycholate and $0.4 \%$ BSA for $20 \mathrm{~h}$, at $22^{\circ} \mathrm{C}$ in stirring; $100 \%$ recovered activity). The presence of a polar head group in sn-3 position was indicated by inactivation with phospholipase $\mathrm{C}(0.05 \mathrm{mg} / \mathrm{ml}$ Tris-buffered saline, $\mathrm{pH} 8$, containing 10 $\mathrm{mM} \mathrm{CaCl}_{2}$ for $22 \mathrm{~h}$, at $22^{\circ} \mathrm{C}$ in stirring; $5-10 \%$ recovered activity).

The specificity of rabbit platelet aggregation induced by PAF derived from IL-1-stimulated HEC was inferred from the inhibitory effect of CV-3988, a PAF antagonist (36). Preincubation of washed rabbit platelets prepared as described (33) with 5-10 $\mu \mathrm{M} \mathrm{CV}-3988\left(5 \mathrm{~min}\right.$ at $\left.37^{\circ} \mathrm{C}\right)$ completely inhibited the biological activity of PAF.

Acetyltransferase activity. HEC stimulated for $6 \mathrm{~h}$ in the absence of acetyl-CoA with $10 \mathrm{U} / \mathrm{ml} \mathrm{IL}-1$ as described above were detached with a rubber policeman and resuspended in $1 \mathrm{ml}$ of $0.25 \mathrm{M}$ sucrose and $1 \mathrm{mM}$ dithiotreitol and then sonicated in an ice bath (Labsonic 1510, B. Braun Melsugen AG, Melsugen, Federal Republic of Germany) at 3 pulses, 10 s, $100 \mathrm{~W}$. Protein was determined by the method of Lowry et al. (37). The standard reaction mixture (38) contained 1-O-alkyl-sn-glycero-3phosphocholine (lyso-PAF, $40 \mu \mathrm{M}), 200 \mu \mathrm{M}\left[{ }^{3} \mathrm{H}\right]$ acetyl-CoA $(0.5 \mu \mathrm{Ci})$, $40 \mu \mathrm{g}$ protein in $0.5 \mathrm{ml}$ Tris $\mathrm{HCl} 0.1 \mathrm{M}, \mathrm{pH} \mathrm{6.9}$, and the reaction was performed at $37^{\circ} \mathrm{C}$ for $10 \mathrm{~min}$; it was stopped with $3 \mathrm{ml}$ chloroform/ methanol $(1: 2, \mathrm{vol} / \mathrm{vol})$ and the lipid extracted and chromatographed as above. The layer was scraped in $0.5-\mathrm{mm}$ increments and radioactivity counted in an OCS scintillation liquid.

The radioactivity corresponding to the $R_{f}$ of synthetic PAF $(0.21)$ was used to measure enzymatic activity. The results were corrected for the radioactivity losses in lipid extraction and TLC purification using L3-phosphatidyl-[ $\mathrm{N}$-methyl- $\left.{ }^{3} \mathrm{H}\right]$ choline-1,2 dipalmitoyl as internal standard in both cases. In some experiments, $1-\left[{ }^{14} \mathrm{C}\right]$ palmitoyl-2-acetyl-sn-glycero3-phosphocholine was used as internal standard. Since the results obtained with both lipid standards were comparable, L-3-phosphatidyl-[ $N$-methyl${ }^{3} \mathrm{H}$ ]choline-1,2 dipalmitoyl was used routinely.

The enzymatic activity was linear as a function of the concentration of lysate proteins (up to $60 \mu \mathrm{g}$ ) and the incubation time (up to $20 \mathrm{~min}$ ). For this, the standard reaction was done with $\mathbf{4 0} \mu \mathrm{g}$ protein, for $10 \mathrm{~min}$ at $37^{\circ} \mathrm{C}$. To determine the apparent Michaelis constant $\left(K_{\mathrm{m}}\right)$ for acetyl$\mathrm{CoA}$, in some experiments the concentration of the substrate ranged from 10 to $300 \mu \mathrm{M}$.

\section{Results}

IL-1-induced PAF production by HEC. As shown in Table I, IL-1 at $10 \mathrm{U} / \mathrm{ml}$, after $6 \mathrm{~h}$ of incubation with HEC, increased PAF content in the cell extract and in the supernatant. This effect was amplified by the addition of increasing concentrations of acetyl-CoA. Acetyl-CoA, in the absence of IL-1, did not in- 
Table I. Effect of Acetyl-CoA on IL-1-induced $P A F$ Production by HEC

\begin{tabular}{|c|c|c|c|}
\hline \multirow{2}{*}{\multicolumn{2}{|c|}{ Additions }} & \multicolumn{2}{|l|}{ PAF } \\
\hline & & Cell extract & Supernatant \\
\hline & & $\mathrm{ng} / 1.5 \times 10^{5}$ cells & $\mathrm{ng} / 1.5 \times 10^{5}$ cells \\
\hline None & & $0.4 \pm 0.02$ & $<0.01$ \\
\hline \multicolumn{4}{|c|}{ Acetyl-CoA (mM) } \\
\hline 0.1 & & $0.6 \pm 0.05$ & $<0.01$ \\
\hline \multicolumn{4}{|c|}{ IĹ-1 $(U / m l)$} \\
\hline 10 & & $2.6 \pm 0.2^{*}$ & $1.1 \pm 0.1$ \\
\hline \multicolumn{4}{|c|}{ IL-1 $(U / m l)$-Acetyl-CoA $(m M)$} \\
\hline 10 & 0.01 & $2.6 \pm 0.1^{*}$ & $1.0 \pm 0.09$ \\
\hline 10 & 0.05 & $4.3 \pm 0.4^{*}$ & $1.7 \pm 0.1$ \\
\hline 10 & 0.1 & $6.7 \pm 0.3^{*}$ & $2.3 \pm 0.1$ \\
\hline
\end{tabular}

HEC monolayers $\left(1.5-2 \times 10^{5}\right.$ cells $/ 4 \mathrm{~cm}^{2}$ culture well) were incubated with crude IL-1 and acetyl-CoA alone or in combination. After $6 \mathrm{~h}$ the amount of PAF in the cell extract and supernatant was determined. The values are means \pm SEM of three experiments performed on three separate cell culture. $\quad P<0.01$ vs. untreated cells, Dunnett's test.

crease PAF production by HEC. Since acetyl-CoA acting as a substrate for PAF biosynthesis $(39,40)$ amplified the response induced by IL-1, it was included routinely in assays unless otherwise specified. The concentration of acetyl-CoA used for assays was $0.1 \mathrm{mM}$. This concentration has been used by other authors to amplify the response of a series of stimuli in other cell types without toxic effects $(39,40)$. In our hands, this concentration of acetyl-CoA in the presence or absence of IL-1 did not induce loss of HEC integrity (up to $24 \mathrm{~h}$ incubation) as judged by ${ }^{51} \mathrm{Cr}$ release performed as described (10) and trypan blue exclusion (four experiments).

Fig. $2 A$ shows the results of a typical experiment in which HEC were exposed to crude IL-1 for various times in culture and PAF production was measured. Very little PAF was found

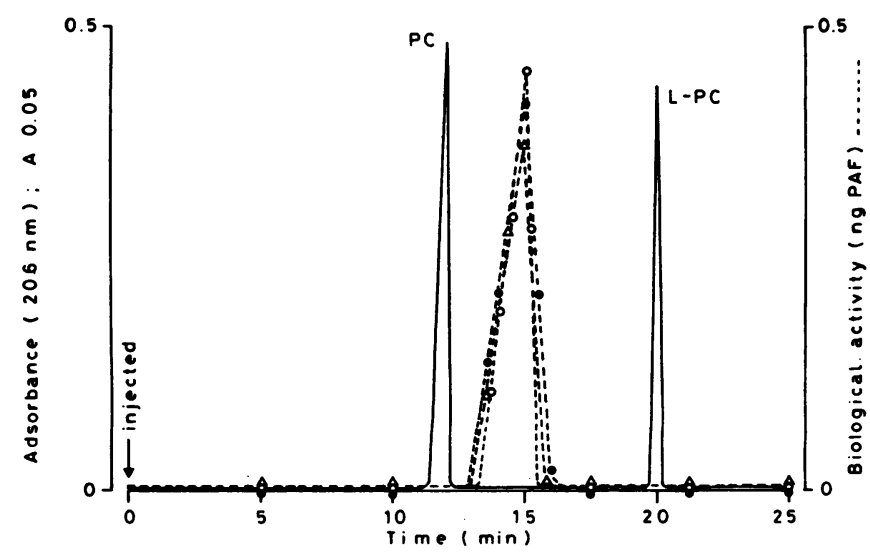

Figure 1. Typical HPLC of TLC-purified lipids $\left(R_{f} 0.15-0.22\right)$ from IL-1- (10 U/ml) and A23187- (1 $\mu \mathrm{M})$ stimulated HEC, using as a solvent system at the start, $96 \%$ isopropanol- $n$-hexane $(1: 1, \mathrm{vol} / \mathrm{vol})$ and $4 \%$ water with a linear gradient to $8 \%$ water over 15 min. Results were similar with TLC-purified lipids extracted from the supernatants of IL-1- (10 U/ml) stimulated HEC. Synthetic PAF, (O); A23187-induced PAF, (๑); IL-1-induced PAF, ( $\Delta$ ). in unstimulated cell extract and in the supernatant, whereas IL1 induced an appreciable PAF increase in the cell extract. This effect was already apparent after $2 \mathrm{~h}$ of incubation, reached a plateau after $4 \mathrm{~h}$, and declined after 18-24 h. Only a small amount of PAF was found in the cell supernatant throughout the experiment. Fig. $2 B$ shows the results obtained in four experiments performed in four separate cell cultures. The results reported in Fig. 2 were obtained with a crude preparation containing IL-1 activity. It was therefore important to establish whether purified and recombinant IL-1 had the same effect on HEC, as illustrated in Fig. 3, which summarizes results from four experiments in which a $10 \mathrm{U} / \mathrm{ml}$ concentration was utilized and crude, purified, and recombinant IL-1 were similarly effective in inducing PAF in HEC.

The three IL-1 preparations were similar in terms of kinetics of induction and dose-response relationship, as illustrated in Fig. 4, which reports the results obtained in four experiments comparing different concentrations of crude and recombinant IL-1.

LPS did not play an appreciable role in induction of PAF production by IL-1 based on the following evidence: $(a)$ LPSfree $(<0.1 \mathrm{ng} / \mathrm{ml}$ of a solution containing $100 \mathrm{U} / \mathrm{ml}$ of IL-1, as detected in the Limulus assay), purified, and recombinant IL-1 induced PAF generation as effectively (on a per IL-1 unit basis) as crude IL-1 contaminated by LPS (Figs. 3 and 4); (b) LPS at a concentration up to $10 \mu \mathrm{g} / \mathrm{ml}$ had little effect on PAF generation in the cell extract and supernatant compared with unstimulated cells (Fig. 5); (c) the lipid A-reactive antibiotic polymixin B $(10 \mu \mathrm{g} / \mathrm{ml})$ did not inhibit PAF production induced by crude IL-1 in the cell extract and in the supernatant (Fig. 5). Polymixin B binds LPS in a stoichiometric manner. Therefore these conditions provide a large excess of this reagent.

It was of interest to elucidate whether human lymphokines other than IL-1 interacted with HEC. In three experiments performed on three different cell cultures, recombinant interleukin 2 (at 5-10 U/ml), interferon- $\alpha$ and $-\gamma$, and natural interferon$\beta($ at $500-1,000 \mathrm{U} / \mathrm{ml}$ ) had no effect on PAF generation or release by HEC after $6 \mathrm{~h}$ of incubation (data not shown).

As shown in Table II, treatment of the cells with cycloheximide caused about $89 \%$ inhibition of IL-1 induction of cellassociated PAF and $100 \%$ inhibition of PAF released in the supernatant.

Since IL-1 has been shown to increase $\mathrm{PGl}_{2}(10)$ and tissue procoagulant activity (PCA) (9) in HEC, we tested the effects of aspirin and hirudin in order to elucidate the possible role of $\mathrm{PGl}_{2}$ or thrombin on IL-1-induced PAF production. When the cells were treated for the duration of the experiment, with aspirin at a concentration of $0.5 \mathrm{mM}$ (which completely blocks $\mathrm{PGl}_{2}$ synthesis induced by $10 \mathrm{U} / \mathrm{ml} \mathrm{IL-1}$ (10), or with hirudin (10 U/ $\mathrm{ml}$ ), no inhibitory effect on IL-1-induced PAF production was apparent in the cell extract or supernatant (Table II).

Effect of IL-1 on HEC 1-O-alkyl-sn-glycero-3-phosphocholine: acetyl-CoA acetyltransferase. HEC appear to produce PAF by acetylation of the precursor 1-o-alkyl-sn-glycero-3-phosphocholine $(19,20)$. To assess whether IL-1 acted on this mechanism to increase HEC-PAF production, we tested the activity of acetyltransferase in HEC lysates after $6 \mathrm{~h}$ of incubation with IL-1 $(10 \mathrm{U} / \mathrm{ml})$. IL-1 treatment appeared to stimulate acetyltransferase activity. As shown in Fig. 6 and Table III, the observed $K_{\mathrm{m}}$ deduced from a double-reciprocal plot was very similar in stimulated and unstimulated HEC. However, the maximum velocity $\left(V_{\max }\right)$ of the enzyme for IL-1 stimulated HEC was about 3-5 

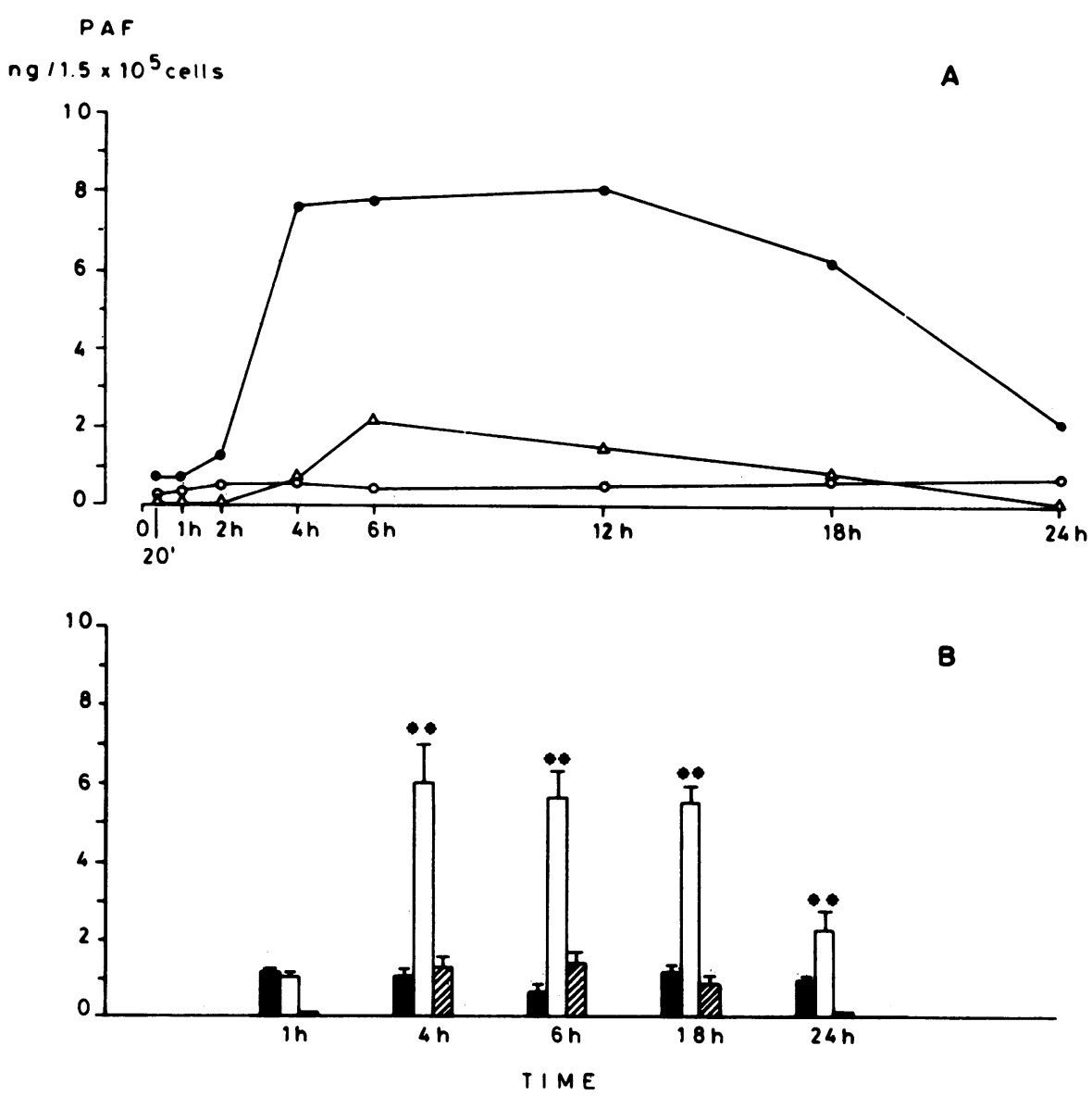

Figure 2. Time course of crude IL-1induced PAF production in HEC. After removal of the culture medium, the monolayers of HEC $\left(1.5-2 \times 10^{5}\right.$ cells/ 4 $\mathrm{cm}^{2}$ culture well) were incubated with serum-free culture medium containing $0.25 \% \mathrm{BSA}$ and $0.1 \mathrm{mM}$ acetyl-CoA in the presence or absence of $10 \mathrm{U} / \mathrm{ml} \mathrm{IL}$ 1. After selected times the amount of PAF in the supernatant and the amount associated to the cells was determined. (A) Time course of IL-1-induced PAF production in a typical experiment. PAF in IL-1-treated cell extract, (๑); PAF in IL-1-treated cell supernatant, $(\Delta)$; PAF in untreated cell extract, (0). PAF was undetectable $\left(<0.01 \mathrm{ng} / 1.5 \times 10^{5}\right.$ cells $)$ in untreated cell supernatant at any time considered. The values are means of duplicate results that agreed to within $\pm 8 \%$ of each other. $(B)$ Time course of crude IL-1-induced PAF production observed in four experiments performed on four separate cell cultures. Black bars represent PAF in untreated cell extract; open bars PAF in IL-1-treated cell extract; hatched bars PAF in IL-1-treated cell supernatant. PAF in the supernatant of IL-1-treated cells at 1 and $24 \mathrm{~h}$ incubation and in the supernatant of untreated cells was $<0.01 \mathrm{ng} / 1.5 \times 10^{5}$ cells: Values are means \pm SEM. ${ }^{* *} P$ $<0.01$ vs. values obtained in untreated cells, Duncan's test. times the $V_{\max }$ of unstimulated cells. The results reported in Fig. 6 and in Table III have been obtained with recombinant IL-1. The three IL-1 preparations gave similar results.

\section{Discussion}

The results reported show that IL-1 stimulates PAF generation in HEC. This activity was found with crude, highly purified, and recombinant IL-1 preparations. The range of concentrations of

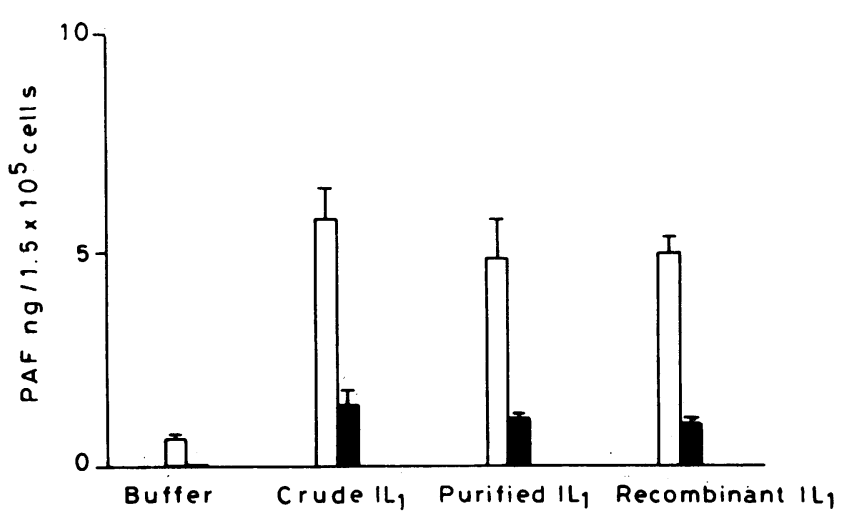

Figure 3. Effect of crude, purified, and recombinant IL-1 on HECPAF production in cell extract and supernatant. The three IL-1 preparations at a concentration of $10 \mathrm{U} / \mathrm{ml}$ were incubated for $6 \mathrm{~h}$ with HEC. Open bars represent PAF in the cell extract and black bars in the supernatant. PAF in the supernatant of untreated cells was $<0.01$ $\mathrm{ng} / 1.5 \times 10^{5}$ cells. Values are means $\pm \mathrm{SEM}$ of four separate experiments performed on four separate cell cultures.
IL-1 able to promote PAF production was very similar to that inducing $\mathrm{PCA}$ and $\mathrm{PGl}_{2}$ in $\mathrm{HEC}(9,10)$. Most of the PAF produced after IL-1 stimulation was associated with the cells and less than $25 \%$ was released in the supernatant. These data are in agreement with findings on other cell types, such as neutrophils stimulated with ionophore A23187 (41) and mast cells sensitized with monoclonal IgE (39). Also of note regarding these cell types is the fact that even in the presence of $0.25 \%$ BSA about $70 \%$

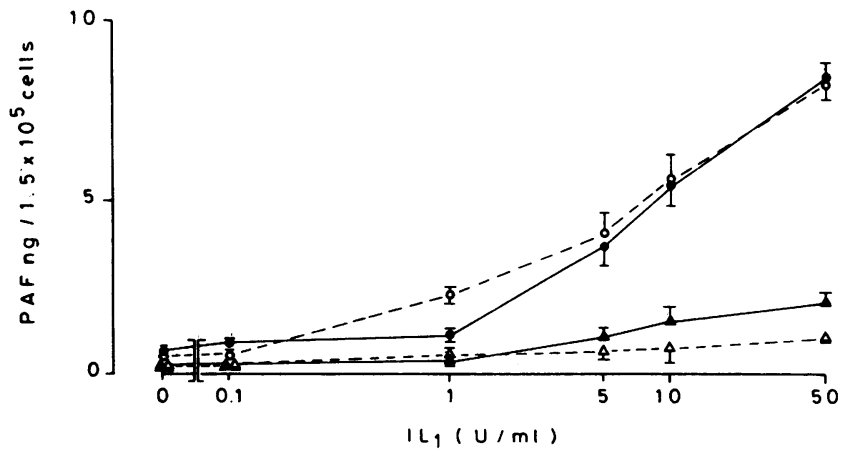

Figure 4. Concentration-dependent stimulation of PAF production by IL-1. After removal of the culture medium, the HEC monolayers were incubated with increased concentration of IL-1. After $6 \mathrm{~h}$ the amount of PAF in the cell extract and in the supernatant was determined. PAF in crude IL-1-treated cell extract, (๑); PAF in recombinant IL-1treated cell extract, (O); PAF in crude IL-1-treated cell supernatant, $(\triangle) ;$ PAF in recombinant IL-1-treated cell supernatant, $(\Delta)$. Values are means \pm SEM of four experiments performed on four separate cell cultures. 


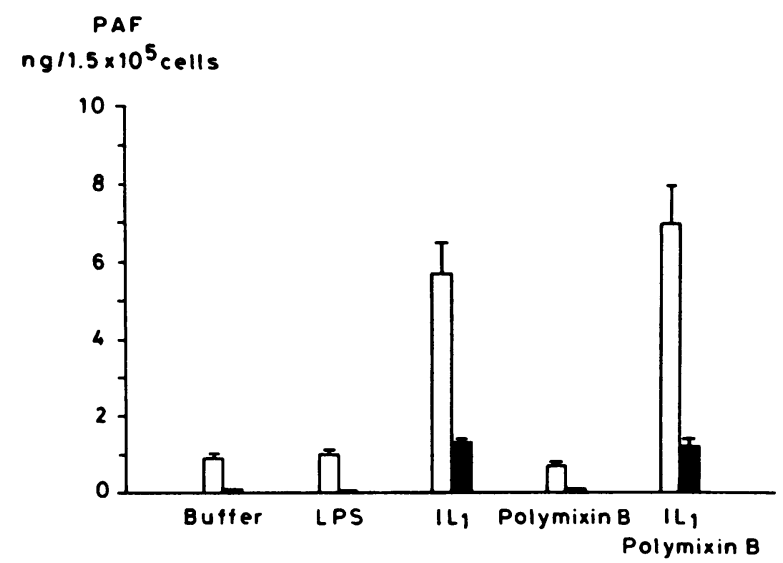

Figure 5. Effect of LPS on crude IL-1-induced PAF production. After removal of the culture medium, the monolayers of HEC were incubated with LPS (10 $\mu \mathrm{g} / \mathrm{ml})$; crude IL-1 $(10 \mathrm{U} / \mathrm{ml})$; polymixin B (10 $\mu \mathrm{g} / \mathrm{ml})$; and IL-1 plus polymixin B. After $6 \mathrm{~h}$ of incubation the amount of PAF in the cell extract (open bars) and in the supernatant (black bars) was evaluated. PAF in the supernatant of untreated cells or LPS and polymixin B-treated cells was $<0.01 \mathrm{ng} / 1.5 \times 10^{5}$ cells. The values are means \pm SEM of three experiments performed on three separate cell cultures.

of PAF in neutrophils and $25 \%$ of PAF in mast cells remained associated to the cells and not released into the medium. In HEC it appears that the amount of PAF released by the cells depends on the type of stimulus used. Camussi et al. (19) showed that angiotensin II, vasopressin, A23187, and anti-Factor VIII antibody induced significant release of this phospholipid into the medium, while thrombin at the first stimulation was ineffective. Prescott et al. (20) subsequently found that thrombin was indeed able to stimulate PAF synthesis by HEC, but PAF remained completely associated to the cells. These authors also showed that histamine, bradykinin, and adenosine triphosphate stimulated PAF associated to HEC without significant release of this substance into the medium. IL-1 appears to induce HECassociated PAF synthesis in a manner similar to the latter series of stimuli.

The fact that most of the PAF produced by HEC after IL-1 stimulation is not released does not necessarily imply that it is biologically inert. Indeed, Zimmerman et al. (42) showed that thrombin stimulation of HEC increased the adherence of polymorphonuclear leukocytes (PMNS) to these cells. This thrombin effect presented the same time course and concentration depen-

Table II. Effect of Cycloheximide, Aspirin, and Hirudin Treatment of the Cells on IL-1-induced PAF Production

\begin{tabular}{lll}
\hline & PAF & \\
\cline { 2 - 3 } Treatment & Cell extract & Supernatant \\
\hline & $n g / 1.5 \times 10^{5}$ cells & $n g / 1.5 \times 10^{5}$ cells \\
None & $7.8 \pm 0.8$ & $1.3 \pm 0.09$ \\
Cycloheximide $(10 \mu \mathrm{g} / \mathrm{ml})$ & $0.9 \pm 0.08$ & $<0.01$ \\
Aspirin $(0.5 \mathrm{mM})$ & $6.9 \pm 0.6$ & $1.9 \pm 0.1$ \\
Hirudin $(10 \mathrm{U} / \mathrm{ml})$ & $6.2 \pm 0.5$ & $1.9 \pm 0.2$ \\
\hline
\end{tabular}

HEC monolayers were incubated with crude IL-1 $(10 \mathrm{U} / \mathrm{ml})$ for $6 \mathrm{~h}$. All the treatments were added to the cells for the duration of the experiment. The values are means \pm SEM of three experiments performed on three separate cell cultures.

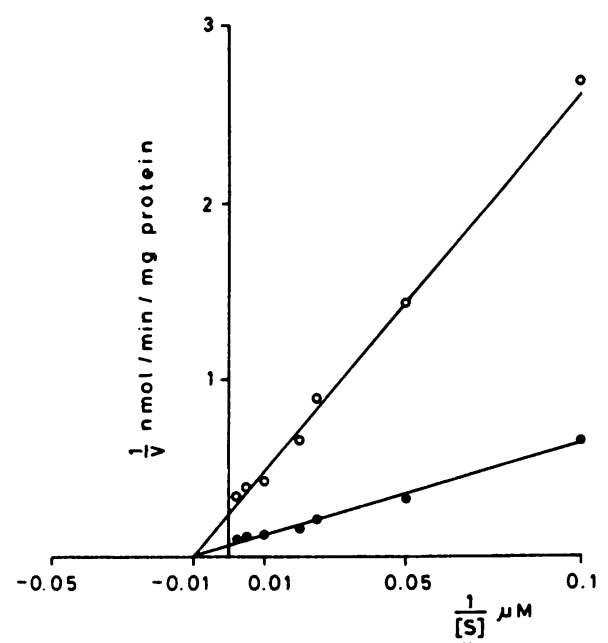

Figure 6. Double reciprocal plot for acetyl-CoA acetyltransferase from control cells (0) and IL-1-stimulated cells, $10 \mathrm{U} / \mathrm{ml}$ for $6 \mathrm{~h},(\bullet)$. The concentrations of lyso-PAF and proteins were $40 \mu \mathrm{M}$ and $40 \mu \mathrm{g}$, respectively, and the incubation time was $10 \mathrm{~min}$ at $37^{\circ} \mathrm{C}$. The results are the average of duplicate determinations and correspond to Experiment 1 reported in Table III.

dence as thrombin-stimulated PAF production by HEC, and was selectively abolished by PMNS desensitization to PAF. This strongly suggests that PAF synthesized by HEC was appropriately located to interact with adjacent PMNS. Moreover, recent evidence shows that IL-1 treatment of HEC markedly increases leukocyte adhesion to these cells (11) with a time course very similar to that of IL-1-induced PAF production. It is therefore conceivable that PAF production by HEC after IL-1 stimulation could actively contribute to leukocyte activation and adhesion to the cell membrane.

The induction of PAF by IL-1 required a long interaction with $\mathrm{HEC}(>2 \mathrm{~h})$ and lasted several hours. In contrast, induction of PAF production in HEC by other stimuli like A23187,

Table III. Effect of IL-1 on 1-o-alkyl-sn-glycero-3-phosphocholine: Acetyl-CoA Acetyltransferase Activity in Lysate HEC

\begin{tabular}{lcll}
\hline & $V_{\max }$ & $K_{\mathbf{m}}$ & $V_{\mathbf{m}}$ IL-1 per control \\
\hline & $p m o l / n g$ per min & $\mu M$ & \\
$\begin{array}{l}\text { Experiment } 1 \\
\quad \text { Control }\end{array}$ & 3.6 & & \\
$\quad$ IL-1 & 15.8 & 91.9 & \\
Experiment 2 & & 92.7 & 4.3 \\
$\quad$ Control & 4.0 & & \\
$\quad$ IL-1 & 14.8 & 95.2 & \\
Experiment 3 & & 89.0 & 3.7 \\
$\quad$ Control & 3.1 & 87.1 & \\
IL-1 & 15.3 & 86.3 & 4.9 \\
\hline
\end{tabular}

Effect of recombinant IL-1 (10 U/ml) on HEC 1-O-alkyl-sn-glycerol-3phosphocholine:acetyl-CoA acetyltransferase activity. After $6 \mathrm{~h}$ stimulation, HEC were sonicated ( 3 pulses, $10 \mathrm{~s}, 100 \mathrm{~W}$ ) in $1 \mathrm{ml} 0.25 \mathrm{M}$ sucrose and $1 \mathrm{mM}$ dithiotreitol. Acetyltransferase activity was assayed (10 min, $37^{\circ} \mathrm{C}$ ) in $0.5 \mathrm{ml}$ Tris $\mathrm{HCl}$ buffer $0.1 \mathrm{M}, \mathrm{pH} 6.9$, containing $40 \mu \mathrm{g}$ protein, $40 \mu \mathrm{M}$ lyso-PAF, and different concentrations of [ ${ }^{3} \mathrm{H}$ ]acetyl-CoA $(10-300 \mu \mathrm{M}), K_{\mathrm{m}}$ and $V_{\max }$ were calculated by doublereciprocal plot of acetyltransferase activity. Values are the average of duplicate determinations that agreed within $\pm 12 \%$ of each other. 
thrombin, vasopressin, or angiotensin II is rapid, becoming apparent in only a few minutes, and lasts $<30 \mathrm{~min}(19,20)$. A long time of incubation with IL-1 was required for stimulation of $\mathrm{PGl}_{2}$ and PCA in $\operatorname{HEC}(9,10)$. Cycloheximide blocked the effect of IL-1 on $\mathrm{PGl}_{2}, \mathrm{PCA}(9,10)$, and PAF production. This observation together with the long time-course which characterizes IL-1-induced activities, suggests that the mechanism of action of this lymphokine is protein synthesis-dependent.

An increase in 1-o-alkyl-sn-glycero-3-phosphocholine: acetylCoA acetyltransferase activity has been shown to be the principal mechanism of PAF generation in different cell types induced by a series of stimuli $(23,40,43,44)$. Acetyltransferase was measured in unstimulated and IL-1-stimulated HEC. The study of enzymatic activity in cell extracts showed a three to fivefold increase in $V_{\max }$ after IL-1 stimulation with no change in the $K_{\mathrm{m}}$ values. Similarly, Ninio et al. (23) showed that A23187 stimulation of PAF production in rat peritoneal cells was accompanied by a rapid increase in the $V_{\max }$ of the acetyltransferase with no change in the $K_{\mathrm{m}}$. Other authors have shown that acetyltransferase activity might be stimulated by reversible phosphorylation of the enzyme (45). At present, further data are required to elucidate the mechanism of action of IL- 1 on acetyltransferase and either activation of the enzyme or de novo synthesis can be suggested.

The in vivo relevance of the modulation of HEC-PAF production in HEC by IL-1 is a matter of speculation. PAF is a very potent inducer of platelet aggregation (46), leukocyte activation (47), and neutrophil adhesion to HEC (22). The range of active PAF concentrations for these cells $(22,46,47)$ is very close to those in HEC extracts after IL-1 stimulation. In vivo PAF administration has been repeatedly shown to induce a series of cardiovascular effects, platelet aggregation, and leukocyte activation, but the role of HEC-produced PAF in vivo remains to be fully characterized. During IgE-induced systemic anaphylaxis or immune complex-induced neutropenia in the rabbit, PAF release occurs in vivo concomitantly to an acute thrombocytopenia and neutropenia $(32,48,49)$. During these reactions platelets and neutrophils are sequestered in the microvasculature. However, under these experimental conditions, no evidence has been reported of a direct role of endothelial cell-produced PAF in inducing circulating cells to adhere to microvascular endothelial cells. More recently Ito et al. (21) showed that during hyperacute renal allograft rejection in the rabbit, PAF is locally released in the renal microvasculature and platelets and neutrophils aggregate and adhere to the endothelium. This suggests that the endothelium stimulated by transplantation antibodies could be the source of PAF.

Even if more studies are required to investigate its biological relevance, the present demonstration of PAF production by IL1-stimulated HEC strengthens the concept of a reciprocal interaction between the immune system and vascular cells and further indicates that HEC are able to generate mediators that can locally influence platelets and inflammatory cell functions.

In this study, murine recombinant IL-1 from the P388 D1 macrophage line (27) induced synthesis of PAF in HEC. Recently complimentary (c) DNA clones of human IL-1 have been isolated $(50,51)$. These cDNAs encode proteins with IL-1 activity on a $\mathrm{T}$ cell line or on thymocytes, but are only distantly related (51). Evidence of heterogeneity of proteins with IL-1 activity also comes from studies on purified natural material (52). The murine recombinant IL-1 used in this study is closely related to the human cDNA clone designated $\alpha$, having $62 \%$ identical positions (51). As soon as human recombinant IL-1s become available, it will be important to assess their effect on HEC, to de- termine whether all proteins with IL-1 activity affect endothelial and induce the same spectrum of responses in vascular cells.

\section{Acknowledgments}

Antonella Palmiero, Judith Baggot, Annamaria Chimienti, and Vincenzo and Felice De Ceglie helped prepare the manuscript.

This work was partially supported by the Italian National Research Council (Progetto Finalizzato Oncologia, contract Nos. 84.00656.44 and 84.00415.44) and by Regione Piemonte (Ricerca Finalizzata No. 35). F. Breviario is the recipient of a fellowship from Avv. F. Maironi.

\section{References}

1. Baldwin, W. M. III. 1982. The symbiosis of immunocompetent and endothelial cells. Immunol. Today. 3:267-269.

2. Dejana, E., F. Breviario, G. Balconi, V. Rossi, G. Remuzzi, G. de Gaetano, and A. Mantovani. 1984. Stimulation of prostacyclin synthesis in vascular cells by mononuclear cell products. Blood. 64:1280-1283.

3. Martin, B. M., M. A. Gimbrone Jr., E. R. Unanue, and R. S. Cotran. 1981. Stimulation of nonlymphoid mesenchymal cell proliferation by a macrophage-derived growth factor. J. Immunol. 126:15101515.

4. Polverini, P. J., R. S. Cotran, M. A. Gimbrone Jr., and E. R. Unanue. 1977. Activated macrophages induce vascular proliferation. Nature (Lond.). 269:804-806.

5. Cohen, M. C., P. T. Picciano, W. J. Douglas, T. Yoshida, D. L. Kreutzer, and S. Cohen. 1982. Migration inhibition of endothelial cells by lymphokine-containing supernatants. Science (Wash. DC). 215:301303.

6. Bagby, G. C. Jr., E. McCall, K. A. Bergstrom, and D. Burger. 1983. A monokine regulates colony-stimulating activity production by vascular endothelial cells. Blood. 62:663-668.

7. Pober, J. S., M. A. Gimbrone, Jr., R. S. Cotran, C. S. Reiss, S. J. Burakoff, W. Fiers, and K. A. Ault. 1983. Ia expression by vascular endothelium is inducible by activated $\mathrm{T}$ cells and by human gammainterferon. J. Exp. Med. 157:1339-1353.

8. Dinarello, C. A. 1984. Interleukin-1 and the pathogenesis of the acute-phase response. $N$. Engl. J. Med. 311:1413-1418.

9. Bevilacqua, M. P., J. S. Pober, G. R. Majeau, R. S. Cotran, and M. A. Gimbrone, Jr. 1984. Interleukin 1 (IL-1) induces biosynthesis and cell surface expression of procoagulant activity in human vascular endothelial cells. J. Exp. Med. 160:618-623.

10. Rossi, V., F. Breviario, P. Ghezzi, E. Dejana, and A. Mantovani. 1985. Prostacyclin synthesis induced in vascular cells by interleukin-1. Science (Wash. DC). 229:174-176.

11. Bevilacqua, M. P., J. S. Pober, M. E. Wheeler, R. S. Cotran, and M. A. Gimbrone Jr. 1985. Interleukin 1 acts on cultured human vascular endothelium to increase the adhesion of polymorphonuclear leukocytes, monocytes, and related leukocyte cell lines. J. Clin. Invest. 76:20032011.

12. Pinckard, R. N., L. M. McManus, and D. J. Hanahan. 1982. Chemistry and biology of acetyl glyceryl phophorylcholine (platelet-activating factor). In Advances in Inflammation Research. G. Weissman, editor. Raven Press, New York. 4:142-180.

13. Camussi, G., P. Arese, C. Tetta, F. Bussolino, R. Coda, and A. Vercellone. 1983. Platelet activating factor. In Glomerular Injury 300 Years After Morgagni. T. Bertani and G. Remuzzi, editors. Wichtig Editore, Milan. 89-118.

14. Snyder, F. 1985. Chemical and biochemical aspects of platelet activating factor: a novel class of acetylated ether-linked choline-phospholipids. Med. Res. Rev. 5:107-140.

15. Bussolino, F., M. Aglietta, F. Sanavio, A. Stacchini, D. Lauri, and G. Camussi. Alkyl ether phosphoglycerides influence calcium fluxes into human endothelial cells. J. Immunol. 135:2748-2753.

16. Shukla, S. D., D. B. Buxton, M. S. Olson, and D. J. Hanahan. 1983. Acetylglyceryl ether phosphorylcholine. A potent activator of hepatic phosphoinositide metabolism and glycogenolysis. J. Biol. Chem. 258:10212-10214. 
17. Benveniste, J., P. M. Henson, and C. G. Cochrane. 1972. Leukocyte-dependent histamine release from rabbit platelets. The role of IgE, basophils, and a platelet-activating factor. J. Exp. Med. 136:13561377.

18. Camussi, G., I. Pawlowski, F. Bussolino, P. R. B. Caldwell, J. Brentjens, and G. Andres. 1983. Release of platelet activating factor in rabbits with antibody-mediated injury of the lung: the role of leukocytes and of pulmonary endothelial cells. J. Immunol. 131:1802-1807.

19. Camussi, G., M. Aglietta, F. Malavasi, C. Tetta, W. Piacibello, F. Sanavio, and F. Bussolino. 1983. The release of platelet-activating factor from human endothelial cells in culture. J. Immunol. 131:23972403.

20. Prescott, S. M., G. A. Zimmerman, and T. M. McIntyre. 1984. Human endothelial cells in culture produce platelet-activating factor (1-alkyl-2-acetyl-sn-glycero-3-phosphocholine) when stimulated with thrombin. Proc. Natl. Acad. Sci. USA. 81:3534-3538.

21. Ito, S., G. Camussi, C. Tetta, F. Milgrom, and G. Andres. 1984. Hyperacute renal allograft rejection in the rabbit. The role of plateletactivating factor and of cationic proteins derived from polymorphonuclear leukocytes and from platelets. Lab. Invest. 51:148-161.

22. Ingraham, L. M., T. D. Coates, J. M. Allen, C. P. Higgins, R. L. Baehner, and L. A. Boxer. 1982. Metabolic, membrane, and functional responses of human polymorphonuclear leukocytes to platelet-activating factor. Blood. 59:1259-1266.

23. Ninio, E., J. M. Mencia-Huerta, and J. Benveniste. 1983. Biosynthesis of platelet-activating factor (PAF-acether). V. Enhancement of acetyltransferase activity in murine peritoneal cells by calcium ionophore A23187. Biochim. Biophys. Acta. 751:298-304.

24. Colotta, F., G. Peri, A. Villa, and A. Mantovani. 1984. Rapid killing of actinomycin d-treated tumor cells by human mononuclear cells. I. Effectors belong to the monocyte-macrophage lineage. J. Immunol. 132:936-944.

25. Gery, I., P. Davies, J. Derr, N. Krett, and J. A. Barranger. 1981. Relationship between production and release of lymphocyte-activating factor (interleukin 1) by murine macrophage. I. Effects of various agents. Cell. Immunol. 64:293-303.

26. Rosenwasser, L. J., and C. A. Dinarello. 1981. Ability of human leucocyte pyrogen to enhance phytohemagglutinin induced murine thymocyte proliferation. Cell. Immunol. 63:134-142.

27. Lomedico, P. T., U. Gubler, C. P. Hellmann, M. Dukovich, J. G. Giri, Y.-C. E. Pan, K. Collier, R. Semionow, A. O. Chua, and S. B. Mizel. 1984. Cloning and expression of murine interleukin-1 cDNA in Escherichia coli. Nature (Lond.). 312:458-462.

28. Scala, G., P. Allavena, J. Y. Djeu, T. Kasahara, J. R. Ortaldo, R. B. Herberman, and J. J. Oppenheim. 1984. Human large granular lymphocytes are potent producers of interleukin-1. Nature (Lond.). 309: 56-59.

29. Dejana, E., G. Balconi, C. De Castellarnau, B. Barbieri, M. Vergara-Dauden, and G. de Gaetano. 1983. Prostacyclin production by human endothelial and bovine smooth muscle cells in culture. Effect of repeated stimulation with arachidonic acid, thrombin and ionophore A23187. Biochim. Biophys. Acta. 750:261-267.

30. Blight, E. G., and W. J. Dyer. 1959. A rapid method of total lipid extraction and purification. Can. J. Biochem. Physiol. 37:911-917.

31. Demopoulos, C. A., R. N. Pinckard, and D. J. Hanahan. 1979. Platelet-activating factor. Evidence for 1-O-alkyl-2-acetyl-sn-glyceryl-3phosphorylcholine as the active component (a new class of lipid chemical mediators). J. Biol. Chem. 254:9355-9358.

32. Pinckard, R. N., R. S. Farr, and D. J. Hanahan. 1979. Physicochemical and functional identity of rabbit platelet-activating factor (PAF) released in vivo during IgE anaphylaxis with PAF released in vitro from IgE sensitized basophils. J. Immunol. 123:1847-1857.

33. Camussi, G., C. Tetta, M. C. Deregibus, F. Bussolino, G. Segolini, and A. Vercellone. 1982. Platelet-activating factor (PAF) in experimentally-induced rabbit acute serum sickness: Role of basophil-derived PAF in immune complex deposition. J. Immunol. 128:86-94.

34. Blank, M. L., and F. Snyder. 1983. Improved high-performance liquid chromatographic method for isolation of platelet-activating factor from other phospholipids. J. Chromatogr. 273:415-420.
35. Benveniste, J., J. P. Le Couedic, J. Polonsky, and M. Tence. 1977. Structural analysis of purified platelet-activating factor by lipases. Nature (Lond.). 269:170-171.

36. Terashita, Z.-i., S. Tsushima, Y. Yoshioka, H. Nomura, Y. Inada, and K. Nishikawa. 1983. CV-3988-A specific antagonist of platelet activating factor (PAF). Life Sci. 32:1975-1982.

37. Lowry, O. H., N. J. Rosebrough, A. L. Farr, and R. J. Randall. 1951. Protein measurements with the folin phenol reagent. J. Biol. Chem. 193:265-275.

38. Wykle, R. L., B. Malone, and F. Snyder. 1980. Enzymatic synthesis of 1-alkyl-2-acetyl-sn-glycero-3-phosphocholine, a hypotensive and platelet-aggregating lipid. J. Biol. Chem. 255:10256-10260.

39. Mencia-Huerta, J-M., R. A. Lewis, E. Razin, and K. F. Austen. 1983. Antigen-initiated release of platelet-activating factor (PAF-acether) from mouse bone marrow-derived mast cells sensitized with monoclonal IgE. J. Immunol. 131:2958-2964.

40. Jouvin-Marche, E., E. Ninio, G. Beaurain, M. Tence, P. Niaudet, and J. Benveniste. 1984. Biosynthesis of Paf-acether (platelet-activating factor). VII. Precursors of Paf-acether and acetyl-transferase activity in human leukocytes. J. Immunol. 133:892-898.

41. Oda, M., K. Satouchi, K. Yasunaga, and K. Saito. 1985. Molecular species of platelet-activating factor generated by human neutrophils challenged with ionophore A23187. J. Immunol. 134:1090-1093.

42. Zimmerman, G. A., T. M. McIntyre, and S. M. Prescott. 1985. Thrombin stimulates the adherence of neutrophils to human endothelial cells in vitro. J. Clin. Invest. 76:2235-2246.

43. Alonso, F., M. G. Gil, M. Sanchez-Crespo, and J. M. Mato. 1982. Activation of 1-alkyl-2-lysoglycero-3-phosphocholine. Acetyl-CoA transferase during phagocytosis in human polymorphonuclear leukocytes. J. Biol. Chem. 257:3376-3378.

44. Albert, D. H., and F. Snyder. 1983. Biosynthesis of 1-alkyl-2acetyl-sn-glycero-3-phosphocholine (platelet-activating factor) from 1alkyl-2-acyl-sn-glycero-3-phosphocholine by rat alveolar macrophages. Phospholipase A2 and acetyltransferase activities during phagocytosis and ionophore stimulation. J. Biol. Chem. 258:97-102.

45. Leinhan, D. J., and T-C. Lee. 1984. Regulation of platelet activating factor synthesis: modulation of 1-alkyl-2-sn-glycero-3-phosphocholine: Acetyl-CoA acetyltransferase by phosphorylation and dephosphorylation in rat spleen microsomes. Biochem. Biophys. Res. Commun. 120:834-839.

46. McManus, L. M., D. J. Hanahan, and R. N. Pinckard. 1981. Human platelet stimulation by acetyl glyceryl ether phosphorylcholine. J. Clin. Invest. 67:903-906.

47. Shaw, J. O., R. N. Pinckard, K. S. Ferrigni, L. M. McManus, and D. J. Hanahan. 1981. Activation of human neutrophils with 1-Ohexadecyl/octadecyl-2-acetyl-sn-glyceryl-3-phosphorylcholine (platelet activating factor). J. Immunol. 127:1250-1255.

48. Camussi, G., F. Bussolino, C. Tetta, F. Cappio, R. Coda, E. Macchiorlati, M. Alberton, C. Roffinello, and G. Segolini. 1983. Effect of prostacyclin (PGI2) on an immune-complex induced neutropenia. Immunology. 48:625-633.

49. Pinckard, R. N., M. Halonen, J. D. Palmer, C. Butler, J. O. Shaw, and P. M. Henson. 1977. Intravascular aggregation and pulmonary sequestration of platelets during IgE induced systemic anaphylactic shock by platelet depletion. J. Immunol. 119:2185-2191.

50. Auron, P. E., A. C. Werb, L. J. Rosenwasser, S. F. Mucci, A Rich, S. M. Wolff, and C. A. Dinarello. 1984. Nucleotide sequence of human monocyte interleukin 1 precursor cDNA. Proc. Natl. Acad. Sci. USA. 81:7907-7911.

51. March, C. J., B. Mosley, A. Larsen, D. P. Cerretti, G. Braedt, V. Price, S. Gillis, C. S. Henney, S. R. Kronheim, K. Grabstein, P. J. Conlon, T. P. Hopp, and D. Cosman. 1985. Cloning, sequence and expression of two distinct human interleukin-1 complementary DNAs. Nature (Lond.). 315:641-647.

52. Van Damme, J., M. De Ley, G. Opdenakker, A. Billiau, P. De Somer, and J. Van Beeumen. 1985. Homogenous interferon-inducing $22 \mathrm{~K}$ factor is related to endogenous pyrogen and interleukin-1. Nature (Lond.). 314:266-268. 